University of Nebraska - Lincoln

DigitalCommons@University of Nebraska - Lincoln

2005

\title{
Control of Fe(III) site occupancy on the rate and extent of microbial reduction of $\mathrm{Fe}(\mathrm{III})$ in nontronite
}

\author{
Deb P. Jaisi \\ Miami University \\ Ravi K. Kukkadapu \\ Pacific Northwest National Laboratory, ravi.kukkadapu@pnl.gov \\ Dennis D. Eberl \\ US Geological Survey \\ Hailiang Dong \\ Miami University, dongh@muohio.edu
}

Follow this and additional works at: https://digitalcommons.unl.edu/usdoepub

Part of the Bioresource and Agricultural Engineering Commons

Jaisi, Deb P.; Kukkadapu, Ravi K.; Eberl, Dennis D.; and Dong, Hailiang, "Control of Fe(III) site occupancy on the rate and extent of microbial reduction of Fe(III) in nontronite" (2005). US Department of Energy Publications. 159.

https://digitalcommons.unl.edu/usdoepub/159

This Article is brought to you for free and open access by the U.S. Department of Energy at DigitalCommons@University of Nebraska - Lincoln. It has been accepted for inclusion in US Department of Energy Publications by an authorized administrator of DigitalCommons@University of Nebraska - Lincoln. 


\title{
Control of $\mathrm{Fe}(\mathrm{III})$ site occupancy on the rate and extent of microbial reduction of $\mathrm{Fe}(\mathrm{III})$ in nontronite
}

\author{
Deb P. Jaisi, ${ }^{1}$ Ravi K. Kukkadapu, ${ }^{2}$ Dennis D. Eberl, ${ }^{3}$ and Hailiang Dong ${ }^{1} *$ \\ ${ }^{1}$ Department of Geology, Miami University, Oxford, OH 45056, USA \\ ${ }^{2}$ Pacific Northwest National Laboratory, Richland, WA 99352, USA \\ ${ }^{3}$ US Geological Survey, Boulder, CO 80303, USA
}

(Received March 14, 2005; accepted in revised form July 13, 2005)

\begin{abstract}
A quantitative study was performed to understand how Fe(III) site occupancy controls Fe(III) bioreduction in nontronite by Shewanella putrefaciens CN32. NAu-1 and NAu-2 were nontronites and contained $\mathrm{Fe}$ (III) in different structural sites with 16 and $23 \%$ total iron (w/w), respectively, with almost all iron as Fe(III). Mössbauer spectroscopy showed that Fe(III) was present in the octahedral site in NAu-1 (with a small amount of goethite), but in both the tetrahedral and the octahedral sites in NAu-2. Mössbauer data further showed that the octahedral Fe(III) in NAu-2 existed in at least two environments- trans (M1) and cis (M2) sites. The microbial Fe(III) reduction in NAu-1 and NAu-2 was studied in batch cultures at a nontronite concentration of $5 \mathrm{mg} / \mathrm{mL}$ in bicarbonate buffer with lactate as the electron donor. The unreduced and bioreduced nontronites were characterized by X-ray diffraction (XRD), Mössbauer spectroscopy, and transmission electron microscopy (TEM). In the presence of an electron shuttle, anthraquinone-2,6-disulfonate (AQDS), the extent of bioreduction was $11 \%-16 \%$ for NAu-1 but $28 \%-32 \%$ for NAu-2. The extent of reduction in the absence of AQDS was only 5\%-7\% for NAu-1 but 14\%-18\% for NAu-2. The control experiments with heat killed cells and without cells did not show any appreciable reduction $(<2 \%)$. The extent of reduction in experiments performed with a dialysis membrane to separate cells from clays (without AQDS) was $2 \%-3 \%$ for $\mathrm{NAu}-1$ but $5 \%-7 \%$ for NAu-2, suggesting that cells probably released an electron shuttling compound and/or Fe(III) chelator. The reduction rate was also faster in NAu-2 than that in NAu-1. Mössbauer data of the bioreduced nontronite materials indicated that the Fe(III) reduction in NAu-1 was mostly from the presence of goethite, whereas the reduction in NAu-2 was due to the presence of the tetrahedral and trans-octahedral $\mathrm{Fe}(\mathrm{III})$ in the structure. The measured aqueous $\mathrm{Fe}(\mathrm{II})$ was negligible. As a result of bioreduction, the average nontronite particle thickness remained nearly the same (from 2.1 to $2.5 \mathrm{~nm}$ ) for $\mathrm{NAu}-1$, but decreased significantly from 6 to $3.5 \mathrm{~nm}$ for NAu-2 with a concomitant change in crystal size distribution. The decrease in crystal size suggests reductive dissolution of nontronite NAu-2, which was supported by aqueous solution chemistry (i.e., aqueous $\mathrm{Si}$ ). These data suggest that the more extensive Fe(III) bioreduction in NAu-2 was due to the presence of the tetrahedral and the trans-octahedral Fe(III), which was presumed to be more reducible. The biogenic Fe(II) was not associated with biogenic solids or in the aqueous solution. We infer that it may be either adsorbed onto surfaces of nontronite particles/bacteria or in the structure of nontronite. Furthermore, we have demonstrated that natural nontronite clays were capable of supporting cell growth even in medium without added nutrients, possibly due to presence of naturally existing nutrients in the nontronite clays. These results suggest that crystal chemical environment of $\mathrm{Fe}(\mathrm{III})$ is an important determinant in controlling the rate and extent of microbial reduction of $\mathrm{Fe}(\mathrm{III})$ in nontronite. Copyright $\odot 2005$ Elsevier Ltd
\end{abstract}

\section{INTRODUCTION}

Clay minerals are ubiquitous in natural sediments, soils, and sedimentary rocks, and they play an important role in a number of environmental processes, including nutrient cycling, plant growth, contaminant migration, organic matter maturation, and petroleum production (Stucki, 1988; Stucki, 2005). The large surface area and high charge density control the degree of binding of organic and inorganic molecules to clay mineral surfaces (Stucki, 1988). Microbial metal reduction can influence the fate and transport of organic (Lovley et al. 1989b) and inorganic contaminants (Lovley 1995; Lovley and Lloyd, 2000).

* Author to whom correspondence should be addressed (dongh@ muohio.edu).
Iron is an abundant element in soils and clay minerals, and hence iron cycling in different environmental processes has been an area of active research. The mobility and stability of iron is in part controlled by its oxidation state. Previous studies using chemical reductants such as sodium dithionite and hydrazine have shown the effects of the iron oxidation state in clay mineral on swelling, cation exchange and fixation capacity, specific surface area, color, and magnetic exchange interactions of the clay mineral (Stucki, 2005). Since these inorganic chemical reductants are minor components of soils, they are not likely to play a significant role in affecting the iron oxidation state in clay minerals in natural environments (Stucki, 1988). Since microorganisms capable of Fe(III) reduction have been observed at up to $10^{5}$ cells per gram dry weight of agricultural soil (Achtnich et al., 1995), the role of microbes in controlling the oxidation state and cycling of iron has become increasingly recognized. There have been numerous ex- 
amples showing coexistence of microbes and clay minerals in a number of geological environments such as deep soils and rocks up to $2700 \mathrm{~m}$ below the land surface, and high temperatures up to 90 to $100{ }^{\circ} \mathrm{C}$ (Boone et al., 1995; Lovley et al., 2000).

More recent research is focused on biologic reduction of structural Fe(III) in clay minerals, especially in iron rich smectite, and have shown that microbes can also change the physical and chemical properties of clay minerals, but to a different extent (Kostka et al., 1999a, 1999b, 2002; Dong et al., 2003a). There are several mechanisms by which iron-reducing bacteria deliver electrons to solid Fe(III) as reviewed by Lovley et al. (2004). Geobacter species require direct contact with Fe(III) oxides to reduce them. Shewanella species do not require direct contact, because they can produce chelators to solubilize Fe(III) in oxides and release electron-shuttling compounds (Lovley et al., 2004).

There have been a few attempts to determine the roles of crystal chemical environments of $\mathrm{Fe}$ (III) in controlling the rate of reductive dissolution of tetrahedral and octahedral iron by chemical methods (Osthaus, 1956; Komadel et al., 1990, 1998; Madejova et al., 1998; Komadel, 1999) with contrasting results. However, there has been no attempt to understand whether the site occupancy of Fe(III) in the smectite structure has any effect on the extent and rate of microbial reduction of iron. In this investigation, we specifically focused on how Fe(III) distribution between the tetrahedral and octahedral sites affects the bioreduction of $\mathrm{Fe}(\mathrm{III})$ in the nontronite structure.

To achieve this goal, two nontronites (NAu-1 and NAu-2) from the Clay Minerals Society with different Fe(III) structural site occupancy were selected for study. Gates et al. (2002) have shown that NAu-1 contains octahedral Fe(III) with only a minor amount (2\%) of tetrahedral $\mathrm{Fe}(\mathrm{III})$, whereas NAu-2 contains both octahedral (92\%) and tetrahedral (8\%) Fe(III). Our characterization of these two clays revealed further difference in crystal chemical environment of octahedral Fe(III) (see below). Shewanella putrefaciens strain $\mathrm{CN} 32$, a metal-reducing bacterium, was used for all bioreduction experiments. The effect of anthraquinone- 2,6-disulfonate (AQDS), a humic acid analog and an electron shuttle for microbial Fe(III) reduction, was investigated. Chemical extraction methods were used to measure $\mathrm{Fe}(\mathrm{II})$ production and Mössbauer spectroscopy to characterize the distribution of $\mathrm{Fe}$ (II) and $\mathrm{Fe}$ (III) in the nontronite structure before and after bioreduction. The X-ray diffraction (XRD) and transmission electron microscopy (TEM) were used to study mineral transformations associated with the bioreduction of $\mathrm{Fe}(\mathrm{III})$ in nontronite.

\section{MATERIALS AND METHODS}

\subsection{Mineral and Bacterial Culture Preparation}

The bulk samples of nontronites (NAu-1 and NAu-2) were purchased from the Source Clays Repository of the Clay Minerals Society. The nontronite samples were originally uncovered from veins in deeply weathered granulite facies containing schist, gneiss and amphibolite from Uley Graphite Mine near Port Lincoln in South Australia (Keeling et al., 2000). The clay samples were first thoroughly ground, $\mathrm{Na}^{+}$saturated, and sonicated in an ultrasonic water bath. The clay suspension was centrifuged to obtain the size fraction of $0.02-0.5 \mu \mathrm{m}$. This size fraction was repeatedly washed until no $\mathrm{Cl}^{-}$was detected in silver nitrate test.

The nontronite separates were characterized by chemical extractions
(Andradae et al., 2002) and direct current plasma (DCP) emission spectroscopy (Katoh et al., 1999) to determine the total iron and the total $\mathrm{Fe}$ (II) content, by XRD to identify mineralogy, and by TEM to observe specific morphology. The $0.02-0.5 \mu \mathrm{m}$ size fraction of both NAu-1 and NAu-2 was relatively pure and contained 16.4 and $23.4 \%$ total iron, respectively, in their structures with almost all iron as Fe(III) The NAu-1 contained a small amount of iron oxide (goethite) (see below) and traces of illite, quartz, and calcite as revealed by XRD and Mössbauer spectroscopy, whereas NAu-2 was pure without any accessory minerals. The $0.02-0.5 \mu \mathrm{m}$ fraction of clay was made into slurry in sterile bicarbonate buffer $\left(2 \mathrm{~g} / \mathrm{L}\right.$ of reagent grade $\mathrm{NaHCO}_{3}$, and $0.1 \mathrm{~g} / \mathrm{L}$ of $\mathrm{KCl}$ ) at clay concentration of $50 \mathrm{mg} / \mathrm{mL}$. This slurry was purged with 80:20 of $\mathrm{N}_{2}: \mathrm{CO}_{2}$ and then autoclaved. It served as a stock solution for subsequent experiments.

Shewanella putrefaciens CN32 (Subsurface Microbial Culture Collection) was provided courtesy of Dr. David Boone (Portland State Univ.). Strain CN32 was isolated from a subsurface core sample (250 $\mathrm{m}$ beneath the surface) obtained from the Morrison Formation., a formation mined extensively for $\mathrm{U}$, during drilling of a shale-sandstone sequence in northwestern New Mexico (Fredrickson et al., 1998). CN32 was routinely cultured aerobically in tryptic soy broth $(30 \mathrm{~g} / \mathrm{L})$ from the stock culture, which was kept in $40 \%$ glycerol at $-80^{\circ} \mathrm{C}$. After harvesting in TSB until mid to late log phase, CN32 cells were washed three times in bicarbonate buffer. The initial cell density of all cultures was measured by both acridine orange direct count (AODC) and viable cell count.

\subsection{Bacterial Reduction Experiments}

To understand the ability of $S$. putrefaciens $\mathrm{CN} 32$ to reduce Fe(III) in the nontronites, reduction experiments were performed with Fe (III) in nontronite as the sole electron acceptor, lactate as the sole electron donor, and CN32 cells as mediator. This experimental set-up allowed direct contact between bacterial cells and nontronite particles. To examine the possibility of alternative reduction pathways for $S$. putrefactions $\mathrm{CN} 32$, i.e., Shewanella species may be able to reduce Fe(III) in the nontronite structure without direct contact (Newman and Kolter, 2000; Rosso et al., 2003; Lovley et al., 2004), experiments were performed by separating cells from clay by a dialysis membrane that had pore size of $4.8 \mathrm{~nm}$. All the experimental solutions were buffered with bicarbonate at measured $\mathrm{pH}$ 6.8. Separate experiments were conducted with increased $\mathrm{KCl}$ concentration to $13 \mathrm{mM}$ and $54 \mathrm{mM}$, which was 10 and 40 times higher than that of routine experiments, to understand the role of potassium concentration in the clay mineral reaction (especially the formation of illite) (Kim et al., 2004). In a typical experiment with $20 \mathrm{~mL}$ final volume of culture-clay suspension, the concentration of clay was $5 \mathrm{mg} / \mathrm{mL}$ (ca. $14.7 \mathrm{mM} \mathrm{Fe}$ in NAu- 1 and $20.9 \mathrm{mM} \mathrm{Fe}$ in NAu-2) and the concentration of lactate was $20 \mathrm{mM}$. In one experiment, concentration of $\mathrm{Fe}(\mathrm{III})$ was kept constant $(20.9 \mathrm{mM})$ for both NAu-1 and NAu-2 so that the comparison between NAu-1 and NAu-2 was meaningful in terms of both clay and $\mathrm{Fe}(\mathrm{III})$ concentrations. In selected treatments, $0.1 \mathrm{mM}$ of AQDS was added. The experimental tubes were purged with $\mathrm{N}_{2}: \mathrm{CO}_{2}$ gas mix (80:20) and sealed with thick butyl rubber stoppers. One $\mathrm{mL}$ of $\mathrm{CN} 32$ cell suspension was added from a freshly washed culture $\left(2 \times 10^{7}\right.$ cells $/ \mathrm{ml}$, final concentration) in bicarbonate buffer by using a sterile needle and syringe. To fully assess the effects of Fe(III) site occupancy on the rate and extent of bioreduction in the two nontronites, all other parameters were kept constant. Two types of controls were used: one consisted of $1 \mathrm{~mL}$ of sterile bicarbonate buffer in place of CN32 cells; the other consisted of heat killed CN32 cells that were heated to $80^{\circ} \mathrm{C}$ for $1 \mathrm{~h}$ before inoculation. All experiments were incubated at $30^{\circ} \mathrm{C}$ with shaking at $60 \mathrm{rpm}$. All subsequent sampling and handling of culture media and samples were carried out under sterile conditions and anaerobic atmosphere in a Coy anaerobic chamber $\left(95 \% \mathrm{~N}_{2}, 5 \% \mathrm{H}_{2}\right)($ Coy Laboratory Products, Ann Arbor, MI).

\subsection{Analyses}

\subsubsection{Analysis of bacterial $\mathrm{Fe}(\mathrm{III})$ reduction}

At selected time points, the culture tubes were removed from the incubator and $0.5 \mathrm{~mL}$ of cell-mineral suspension was sampled with a 
sterile syringe and was added to a centrifuge tube that contained $0.5 \mathrm{~mL}$ of $1 \mathrm{~N}$ Ultrex $\mathrm{HCl}$. The reaction was allowed for 24 hours before measurement of $\mathrm{Fe}(\mathrm{II})$. This extraction was termed the $0.5 \mathrm{~N} \mathrm{HCl}$ extraction and has been shown to be effective to extract microbially produced $\mathrm{Fe}$ (II) including adsorbed form and $\mathrm{Fe}(\mathrm{II})$ in biogenic solids except for highly crystalline magnetite (Fredrickson et al., 1998; Zachara et al., 1998) and presumably silicates as well. The Fe(II) in a given solution was determined by Ferrozine assay (Stookey, 1970). The rate and extent of microbial reduction of nontronite with time was continuously monitored by measuring Fe(II) production. The amount of $\mathrm{Fe}(\mathrm{II})$ production resulted from the bioreduction was also measured by the titration method (Andradae et al., 2002) following total dissolution of all solids to test if the $0.5 \mathrm{~N} \mathrm{HCl}$ extraction is effective in extracting all biogenic Fe(II) (i.e., that associated with silicates). To measure the aqueous concentration of $\mathrm{Fe}(\mathrm{II})$, the cell-mineral suspension was centrifuged until all the clay particles were settled. The aqueous Fe(II) concentration was measured from supernatant by Ferrozine assay. At several time points concentrations of other cations such as $\mathrm{Si}, \mathrm{Ca}, \mathrm{Fe}$, Al released into the solution were also determined using the direct current plasma (DCP) spectrometry (Katoh et al., 1999).

The change in the number of viable cells over the course of the experiments was monitored by viable cell counts. When cell growth was observed in the experimental medium without added nutrients (lactate, nontronite and bicarbonate buffer only), separate experiments were designed to more systematically investigate cell growth over the course of bioreduction. To understand the role of AQDS to support cell growth, separate experiments were performed where AQDS was used as the sole electron acceptor without any clay. Control experiments included tubes without $\mathrm{CN} 32$ cells and heat killed CN32 cells. At selected time points, the $1.0 \mathrm{~mL}$ of cell-clay suspension was removed from the experimental tube, diluted and plated in agar plate. The number of colony forming units (CFU) was visually counted.

To understand why nontronite clays were capable of supporting cell growth without externally supplied growth-supporting nutrients such as trace metals and vitamins, we determined concentrations of both trace metals and growth supporting nutrients in the NAu- 1 and NAu-2 separates used for the bioreduction experiments. Both NAu-1 and NAu-2 were dissolved into solution using a flux fusion method in lithium metaborate flux. The mixture was fused in a graphite crucible at $950^{\circ} \mathrm{C}$ for $15 \mathrm{~min}$. The molten bead was poured into a $50 \mathrm{~mL} 5 \% \mathrm{HNO}_{3}$ solution containing $3000 \mathrm{ppm} \mathrm{Li}$ used as a matrix modifier, plus $50 \mathrm{ppm}$ Ge and $10 \mathrm{ppm} \mathrm{Cd}$ which were used as internal standards. Trace element analysis was performed on this solution using standard addition. Concentrations of trace elements were determined by direct current plasma spectrometry. Total carbon (TC), total organic carbon (TOC), total nitrogen, and bioavailable phosphorus contents were determined in the STAR lab at the Ohio State University.

\subsection{2. $X$-ray diffraction}

Both unreduced and bioreduced nontronite samples were studied by $\mathrm{XRD}$. The powder XRD patterns were obtained using $\mathrm{CuK} \propto$ radiation with a fixed slit and a scintillation detector. The clay samples were initially $\mathrm{Na}^{+}$saturated for proper identification and to make them monoionic, because the (001) spacing of the oriented clay depends on the type of cations in the interlayer region. The $\mathrm{Na}^{+}$is also a common interlayer cation in natural clays and soils. The samples were then glycolated with ethylene glycol, an organic intercalating reagent used to identify expandable clay minerals. The crystallite size distributions (CSDs) of clay minerals were determined by evaluating XRD data, which can be represented as a Fourier transform series. This yields Fourier coefficients for the various crystallite thicknesses, which can then be treated according to Bertaut-Warren-Averbach (BWA) theory to yield crystallite-thickness distributions (Drits et al., 1998). In cases where illite may be present as a result of nontronite bioreduction (Kim et al., 2004), attempts were made to detect it. To preserve illite/smectite XRD peaks of a stack of crystals (a MacEwan crystallite) not broadened by swelling except by crystallite-thickness effects, the crystals were allowed to swell to the extent that they no longer diffracted coherently by interparticle diffraction. It was accomplished by attaching a polymer polyvinyl-pyrrolidone (PVP-10) to the swelling illite/ smectite basal crystal surfaces. In this procedure, the BWA method provides the thickness of the individual crystals. These data were later used to infer crystal-growth mechanisms for the samples using the GALOPER computer program (Eberl et al., 2000). The layer charge measurement was made according to the procedure suggested by Christidis and Eberl (2003).

\subsubsection{Transmission electron microscopy}

Both unreduced and bioreduced NAu- 2 at time point of 45 days were examined by TEM. The samples were fixed in $2.5 \%$ glutaraldehyde for at least $1 \mathrm{~d}$ and allowed to settle to increase the concentration of solid particles. The procedure for fixation, dehydration, embedding, and sectioning is described elsewhere (Dong et al., 2003a). The JEOL 100S transmission electron microscope was used to analyze morphology at an accelerating voltage of $80 \mathrm{kV}$.

\subsubsection{Mössbauer spectroscopy}

The structural environments of $\mathrm{Fe}(\mathrm{II})$ and $\mathrm{Fe}(\mathrm{III})$ in pristine, and bioreduced nontronite samples were determined by ${ }^{57} \mathrm{Fe}$ transmission Mössbauer spectroscopy at room temperature (RT) and $12 \mathrm{~K}$. Randomly oriented absorbers were prepared by mixing $\sim 100 \mathrm{mg}$ of dried sample with petroleum jelly. The prepared Mössbauer disks were stored at $-80^{\circ} \mathrm{C}$ in an anoxic chamber until the time of analysis. Details of absorber preparation and instrumentation are identical to those reported in Kukkadapu et al. (2004). A closed-cycle cryostat (ARS, Allentown) was employed for the $12 \mathrm{~K}$ measurements. For measurements at $12 \mathrm{~K}$, only the absorber was at this temperature, and both the source and drive assemblies were still at RT. Modeling of the data were carried out by the Recoil software (University of Ottawa, Canada) using Voigt based spectral fitting routine (Rancourt and Ping, 1991).

\section{RESULTS}

\subsection{Characterization of Unreduced Nontronite}

The DCP measurement for the total iron and the titration measurement for ferrous iron concentration showed that the starting material of NAu-1 contained $16.4 \%$ total iron by weight and only $0.4 \%$ of that was present as Fe(II). The XRD results indicated that $\mathrm{NAu}-1$ had a small amount of goethite and traces of illite, quartz, and calcite. The starting material of NAu- 2 contained $23.4 \%$ total iron by weight and only $0.6 \%$ of the total iron was present as $\mathrm{Fe}(\mathrm{II})$. The XRD results indicated that NAu-2 consisted of pure nontronite with no other Febearing minerals. These results are generally consistent with those reported by Keeling et al. (2000).

\subsubsection{Mössbauer spectroscopy}

3.1.1.1. NAu-1 Room temperature (RT) and 12-K Mössbauer spectra of NAu-1 are shown in Figure 1. The spectra were dominated by a central doublet (RT spectrum: $\delta=0.38$ $\mathrm{mm} / \mathrm{s}$ and $\Delta=0.44 \mathrm{~mm} / \mathrm{s} ; 12-\mathrm{K}$ spectrum: $\delta=0.48 \mathrm{~mm} / \mathrm{s}$ and $\Delta=0.45 \mathrm{~mm} / \mathrm{s}$ ), and a minor sextet (RT spectrum: $\delta=0.38$ $\mathrm{mm} / \mathrm{s}, \varepsilon=-0.17 \mathrm{~mm} / \mathrm{s}$, and $B_{\mathrm{hf}}=34.4$ Tesla; $12-\mathrm{K}$ spectrum: $\delta=0.49 \mathrm{~mm} / \mathrm{s}, \varepsilon=-0.12 \mathrm{~mm} / \mathrm{s}$, and $B_{\mathrm{hf}}=49.9 \mathrm{Tesla} ; 12 \%$ area). The central doublet parameters were typical of octahedral Fe(III) (Murad and Cashion, 2004), which was in agreement with a previous study (Gates et al., 2002). The sextet parameters, both at RT and 12-K, were characteristic of goethite (Murad and Cashion, 2004). It was also evident from RT and $12-\mathrm{K}$ spectra that the particle size of goethite was $>15 \mathrm{~nm}$; small-particulate goethite $(<15 \mathrm{~nm})$ displays doublet feature at RT due to superparamagnetism (Janot et al., 1973). 
A

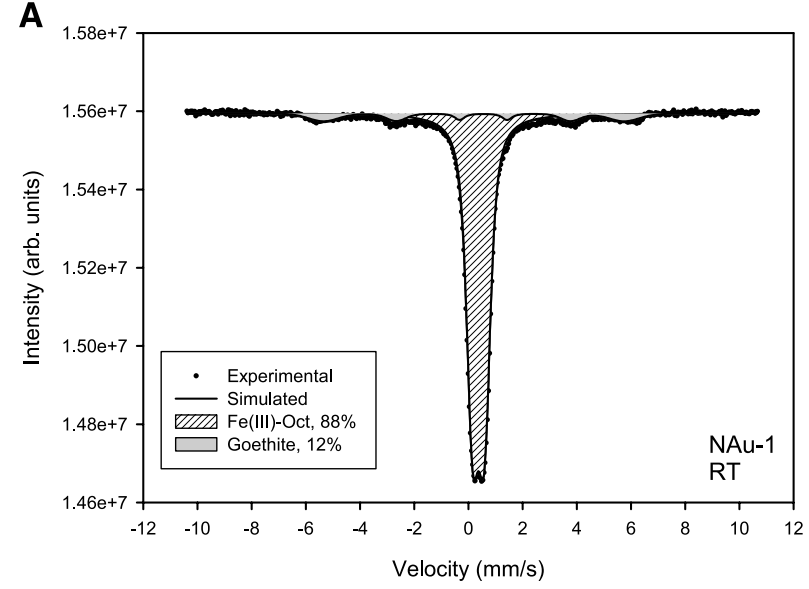

\section{B}

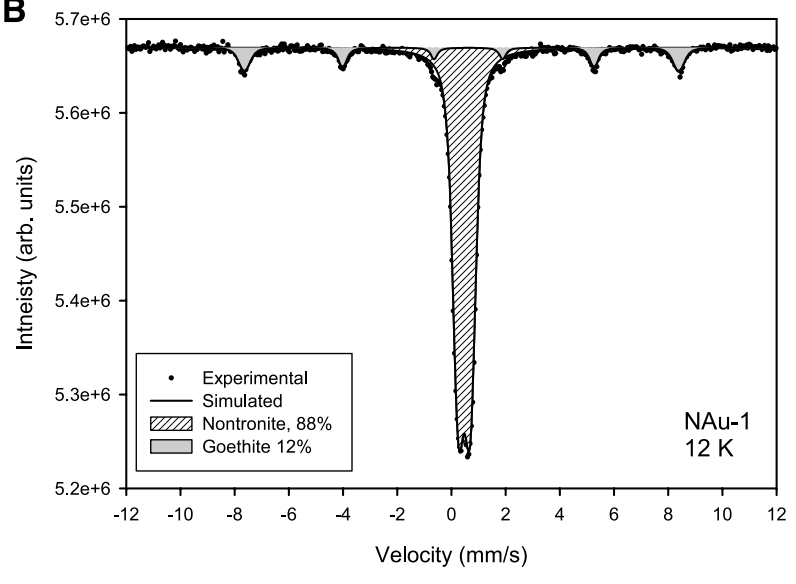

Fig. 1. Mössbauer spectra of the starting NAu-1 at room temperature (RT) (A) and $12 \mathrm{~K}$ (B). The curve fitting at the $12 \mathrm{~K}$ spectrum for NAu-1 shows $12 \%$ of iron oxide forming sextet.

3.1.1.2. NAu-2. Room temperature Mössbauer spectrum of NAu-2 is shown in Figure 2A. The spectrum was identical to that of Riverside nontronite (Boslough et al., 1986 and references therein) but was significantly different from other wellstudied nontronites, such as Garfield and SWa-1 nontronites (Goodman et al., 1976; Luca and Cardille, 1989). Boslough et al. (1986) assigned the spectral feature to two distinct octahedral $\mathrm{Fe}(\mathrm{III})$ environments, $\mathrm{Fe}(\mathrm{III})$ in $\mathrm{M} 1$ site $[\delta=0.42 \mathrm{~mm} / \mathrm{s}$ and $\Delta=1.20 \mathrm{~mm} / \mathrm{s}$; outer doublet (13\% area)] and $\mathrm{Fe}(\mathrm{III})$ in M2 site $[\delta=0.37 \mathrm{~mm} / \mathrm{s}$ and $\Delta=0.34 \mathrm{~mm} / \mathrm{s}$; inner doublet (87\% area)]. Contribution due to tetrahedral Fe(III) was not included in their fit. The Boslough's assignment of the two octahedral doublets was consistent with that by Goodman et al. (1976) who described the Mössbauer spectra of untreated nontronites from a variety of localities. Goodman et al. (1976) fitted the spectra with three doublets corresponding to transoctahedral Fe(III), cis-octahedral Fe(III) and tetrahedral Fe(III). The two doublets from octahedral Fe(III) were assigned to the two crystallographically distinct types of coordination site (M1 and M2), with the smaller $\Delta$ being assigned to the M2 site (cis site) and the larger one being assigned to the M1 site (trans site). However, the difference in the $\Delta$ value between the M1 and M2 sites observed by Goodman et al. (1976) was not as large and well-resolved as those observed in the Boslough et al.
A
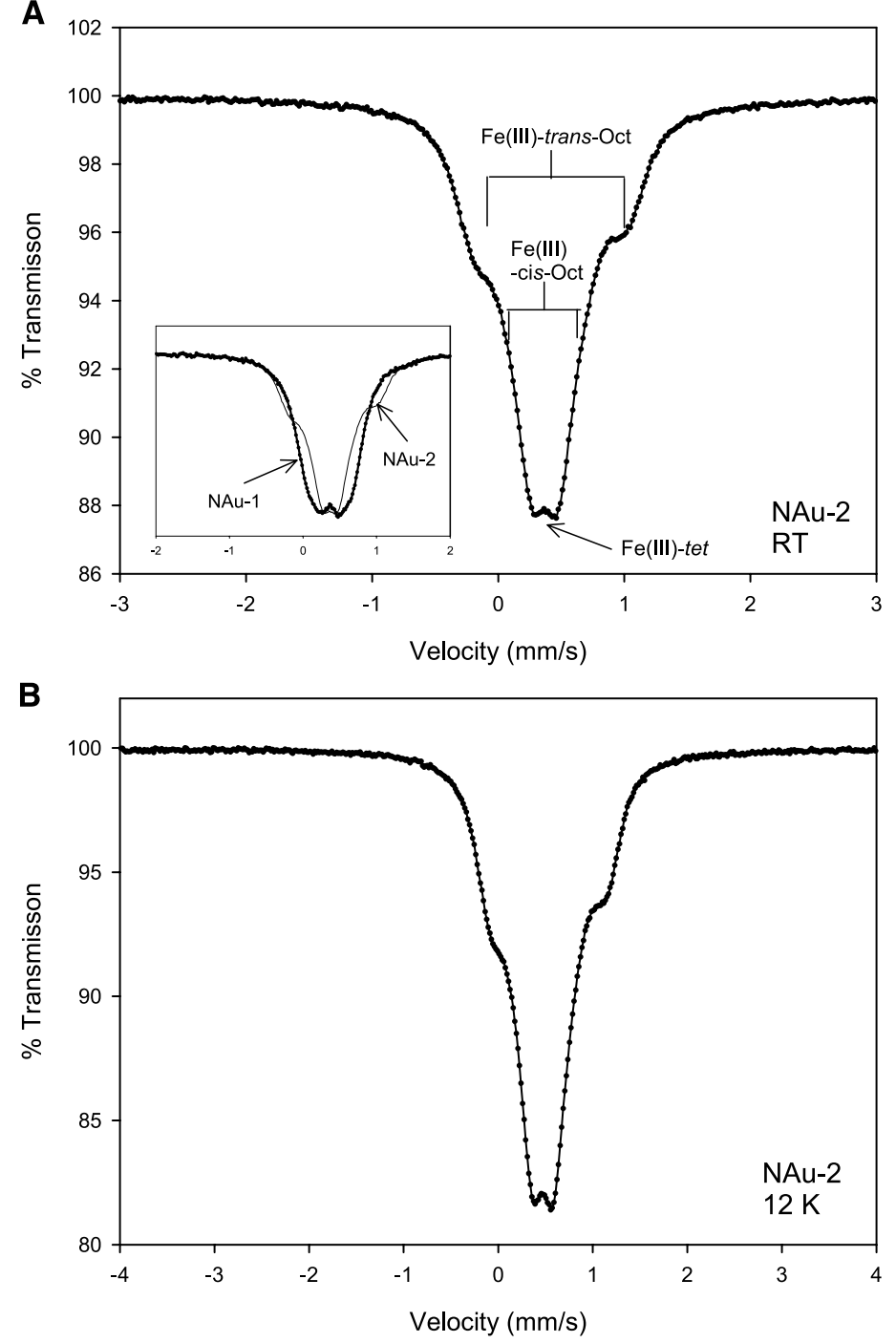

Fig. 2. Möbauer spectra of the starting NAu-2 at RT (A) and $12-\mathrm{K}$ (B). The inset in Figure 2A shows comparison of RT spectra between NAu-1 and NAu-2. The peak assignments (Fe(III)-Trans-Oct, Fe(III)Cis-Oct, and $\mathrm{Fe}(\mathrm{III})-\mathrm{Tet})$ are based on comparisons of MÖssbauer parameters with published literature.

(1986) study and in our study. These comparisons between our observed spectrum and those published in literature indicated that the outer doublet with the larger $\Delta$ value was due to $\mathrm{Fe}$ (III) in the more distorted site (trans, M1 site), and the inner doublet with the smaller $\Delta$ value was due to $\mathrm{Fe}(\mathrm{III})$ in the less distorted site (cis, M2 site) (Fig. 2A). The presence of cis-octahedral $\mathrm{Fe}$ (III) in both NAu-1 and NAu-2 was further consistent with published literature indicating that in most dioctahedral micas the cis-occupied structure (centrosymmetric structure) is more common than the trans structure (Bailey, 1984).

The reported presence of tetrahedral $\mathrm{Fe}$ (III) in NAu-2 (up to 9\%; Gates et al. 2002), and an apparent contribution from a significantly distorted $\mathrm{Fe}$ (III) environment (with an unusual $\Delta$ $\sim 1.20 \mathrm{~mm} / \mathrm{s}$; Fig. 2A) made it difficult to obtain an unambiguous fit of the spectrum. To our knowledge, there were only a couple of reports, even though not explicitly noted, of Fe(III) environments in nontronite with $\Delta \sim 1.2 \mathrm{~mm} / \mathrm{s}$ (Daynyak and 

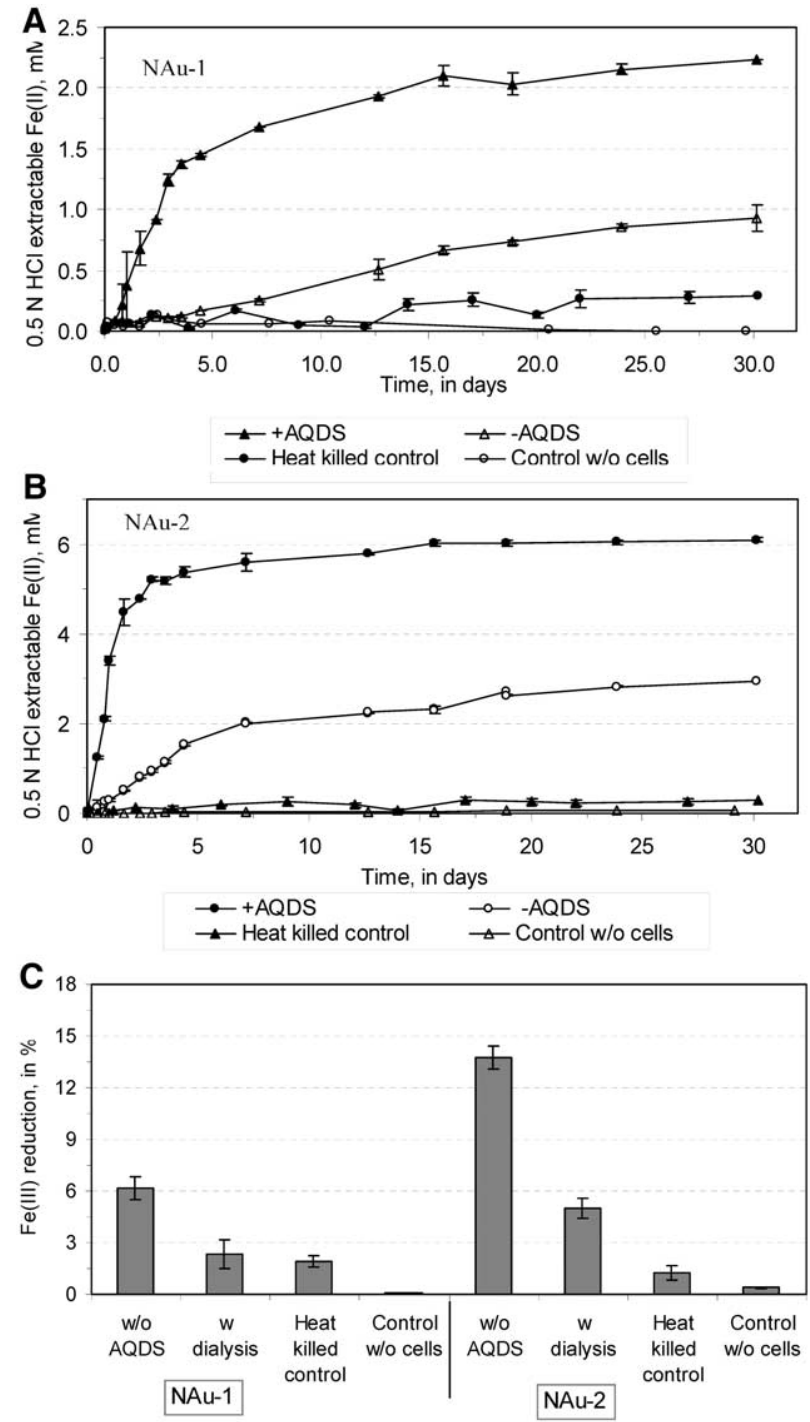

Fig. 3. A) $\mathrm{Fe}(\mathrm{III})$ reduction in NAu-1 as measured by $0.5 \mathrm{HCl}$ extraction, each with four different types of treatment [control (without cells, and heat killed cells), with and without AQDS]. B) Fe(III) reduction in NAu-2 in the four different types of treatment in exactly same environment as that $3 \mathrm{~A}$. The $\mathrm{Fe}$ (III) concentration in NAu-2 was also kept equal t $\mathrm{o}$ that of NAu-1 in Figure 3A. C) The extent of Fe(III) reduction in 28 days in the experiments with and without dialysis membrane (to remove cell-clay contact). The reduction in control experiments is also shown for comparison.

Drits, 1987; Townsend et al. 1987). Daynyak and Drits (1987) fitted a spectral component (indicated by $\mathrm{x}$ in Fig. 2 of Daynyak and Drits) of disoriented nontronite sample with such a species (i.e., large $\Delta$ value of $1.18 \mathrm{~mm} / \mathrm{s}$ ), without providing details. Stucki (2005) eluded that the published structural formulas (Luca and Cardille, 1989; Luca 1991a, 1991b; Luca and Maclachlan, 1992; Manceau et al., 2000a, 2000b; Gates et al., 2002), based on placing excess $\mathrm{Al}^{3+}$ in the tetrahedral sheet, then $\mathrm{Fe}(\mathrm{III})$ if required to satisfy the $\mathrm{Si}^{4+}$ deficit, may underestimate tetrahedral $\mathrm{Fe}(\mathrm{III})$ content. Given these uncertainties, we tentatively and qualitatively identified the RT spectrum of NAu-2 with three doublets: Fe(III)-Trans-Oct (relatively higher $\Delta), \mathrm{Fe}(\mathrm{III})-\mathrm{Cis}-\mathrm{Oct}$, and $\mathrm{Fe}(\mathrm{III})-\mathrm{Tet}$, respectively (Fig. 2A).
The 12-K Mössbauer spectrum (Fig. 2B) was obtained to check for contribution of small-particle Fe-oxides, if any, to the spectrum. Small-particle Fe-oxides (e.g., ferrihydrite, etc.) magnetically order (or at least partial order) at temperatures around $20 \mathrm{~K}$ (Murad and Cashion, 2004). The absence of sextet features at $12 \mathrm{~K}$, therefore, indicated that the doublet features in the RT spectrum of NAu-2 were due to nontronite Fe-sites alone, without any contribution from Fe(III)-oxides. The differences in the apparent isomer shift values between the RT and $12 \mathrm{~K}$ were due to the second-order Doppler shifts. Mössbauer measurements below 12-K (liquid $\mathrm{He}$ range or below) and applied magnetic field Mössbauer measurements are needed for definite identification, which is the focus of our future work. Nontronites have been reported to be magnetically ordered at lower temperatures and in presence of magnetic field (Cardille et al. 1986).

\subsection{Characterization of Bioreduced Nontronite}

\subsubsection{Microbial reduction of nontronite}

The extent and rate of bioreduction were very different between the two nontronites. There was some variability, however, on the rate and extent of reduction in different experiments. Accounting all experiments we performed with constant clay concentration $(5 \mathrm{mg} / \mathrm{mL})$, for $\mathrm{NAu}-1$, the extent of reduction by the end of 15 days in the presence of AQDS reached 11 to $16 \%$; whereas it was 28 to $32 \%$ for $\mathrm{NAu}-2$. When the electron acceptor was kept constant $(20.9 \mathrm{mM})$, the extent of reduction (with AQDS) in first 30 days was 11 and 29\% in NAu-1 and NAu-2, respectively (Fig. $3 \mathrm{~A}$ and $3 \mathrm{~B}$ ). In the absence of AQDS, the reduction was limited to 5 and $14 \%$ in NAu-1 and NAu-2, respectively. The initial rate of reaction was significantly higher in NAu-2 than in NAu-1. For example, in NAu-1 with AQDS, $\sim 54 \%$ of the total reduction (that occurred in 30 days) was attained in 3 days, but for $\mathrm{NAu}-2$, it reached $86 \%$ of the total reduction in the same amount of time (Fig. 3A and $3 \mathrm{~B})$. The reduction without AQDS reached only to 12 and $32 \%$ of the total extent in NAu- 1 and NAu-2, respectively over the same amount of time. The relative difference in the extent of bioreduction between NAu-1 and NAu-2 for a given time remained nearly constant, provided that other experimental parameters were kept constant. The extent of reduction in controls with heat-killed cells was always less than $2 \%$, and that of the controls without cells was less than $1 \%$.

Experiments performed by separating cells from clay particles via dialysis membrane showed that an appreciable amount of reduction occurred even without direct contact. The extent of reduction was $\sim 34 \%-38 \%$ of that obtained when direct contact was allowed, e.g., when dialysis membrane was not used (Fig. 3C). This percentage was similar in both nontronites.

Another set of experiments was run for more than six months to assess the bioreduction behavior over an extended period of time (Figs. 4 and 5). In the presence of AQDS, the bioreduction was insignificant after 37 days in NAu-1 and 14 days in NAu-2. For both nontronites, the reaction was still in progress even after 6 months in the treatments without AQDS. The CN32 cells still remained viable in both treatments (see below). The controls showed negligible reduction in both experiments.

The aqueous concentration of $\mathrm{Fe}(\mathrm{II})$ in the bioreduced 


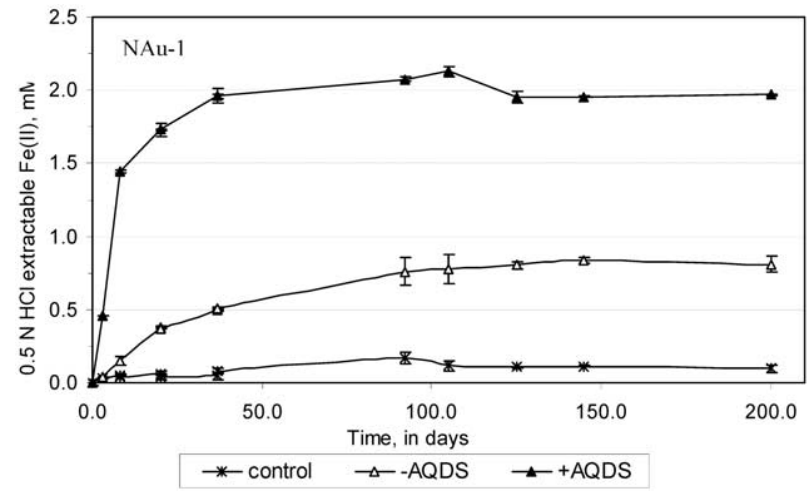

Fig. 4. Extended time reduction experiment in NAu-1 showing the continued reduction in the treatment without AQDS. The bioreduction ceased by the end of 40 days in the treatment with AQDS. Initial clay and cell concentrations were $5 \mathrm{mg} / \mathrm{mL}$ and $1.9 \times 10^{8}$ cells $/ \mathrm{mL}$, respectively, for both treatments (with and without AQDS).

$\mathrm{NAu}-2$ for the long term experiment consisted of an insignificant fraction $(\sim 1-2.5 \%)$ of the total biogenic $\mathrm{Fe}(\mathrm{II})$ as determined by the $0.5 \mathrm{~N} \mathrm{HCl}$ extraction. The amount of $\mathrm{Fe}(\mathrm{II})$ released into the solution increased with time in a similar trend as that for the total $\mathrm{Fe}(\mathrm{II})$. The measurement of other ions in the aqueous solution showed that there was a concurrent increase of silica released into the solution (Fig. 6) with time. The Fe and $\mathrm{Si}$ ions released into the aqueous solution, however, did not maintain their stoichiometric ratio $(\sim 1: 2)$ in the nontronite structure (Keeling et al., 2000).

\subsubsection{Cell growth}

Since the sign of cell growth was observed in the first sets of experiments, a new set of experiment was designed to systematically monitor cell growth with time. Cell growth in NAu-2 was observed especially during the early phase of bioreduction. The rate of cell growth was initially high in the first 4 days (Fig. 7A), after that growth was found to be insignificant. The presence of AQDS promoted more cell growth than that without AQDS. In the experiments where AQDS was used as the

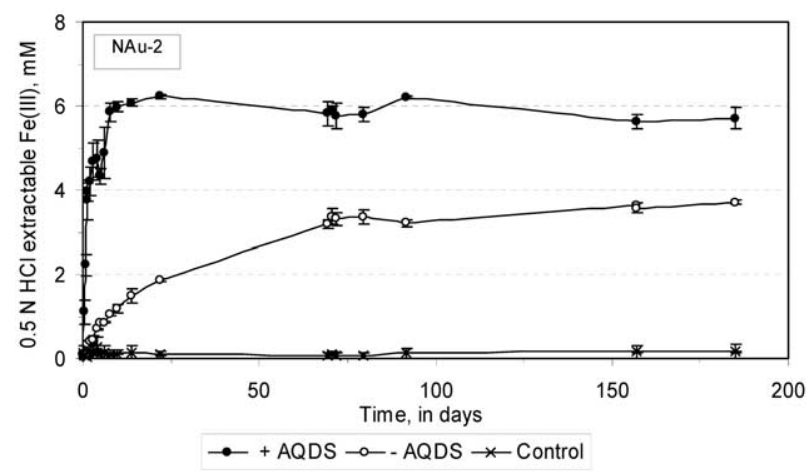

Fig. 5. Extended time reduction experiment in NAu-2 showing the continued reduction in the treatment without AQDS. The bioreduction ceased by the end of 10 days in the treatment with AQDS. Initial clay and cell concentrations were $5 \mathrm{mg} / \mathrm{mL}$ and $1.5 \times 10^{8}$ cells $/ \mathrm{mL}$, respectively.

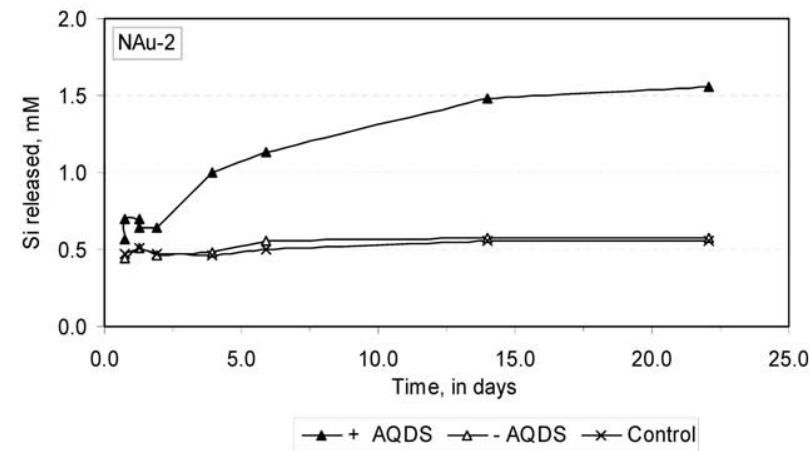

Fig. 6. Change in aqueous Si concentration with time during bioreduction of NAu-2 for three treatments (control, with and without AQDS).

sole electron acceptor without clay, cell growth was not observed (Fig. 7B). Instead, cell viability decreased with time. Cell viability lasted longer in the experiment with higher concentration of AQDS.

The Fe(III) reduction per cell showed that the capacity of a cell to reduce $\mathrm{Fe}$ (III) was initially low. In the treatment without AQDS, the reduction per cell increased steadily to a maximum of $5.4 \times 10^{-5} \mu \mathrm{M}$ of $\mathrm{Fe}$ (II) per cell in 7 days and then almost remained constant or decreased slightly after that time (Fig. 8). In the treatment with AQDS, the reduction per cell peaked at $9.5 \times 10^{-5} \mu \mathrm{M} /$ cell in 2 days. The control experiment did not show any reduction.
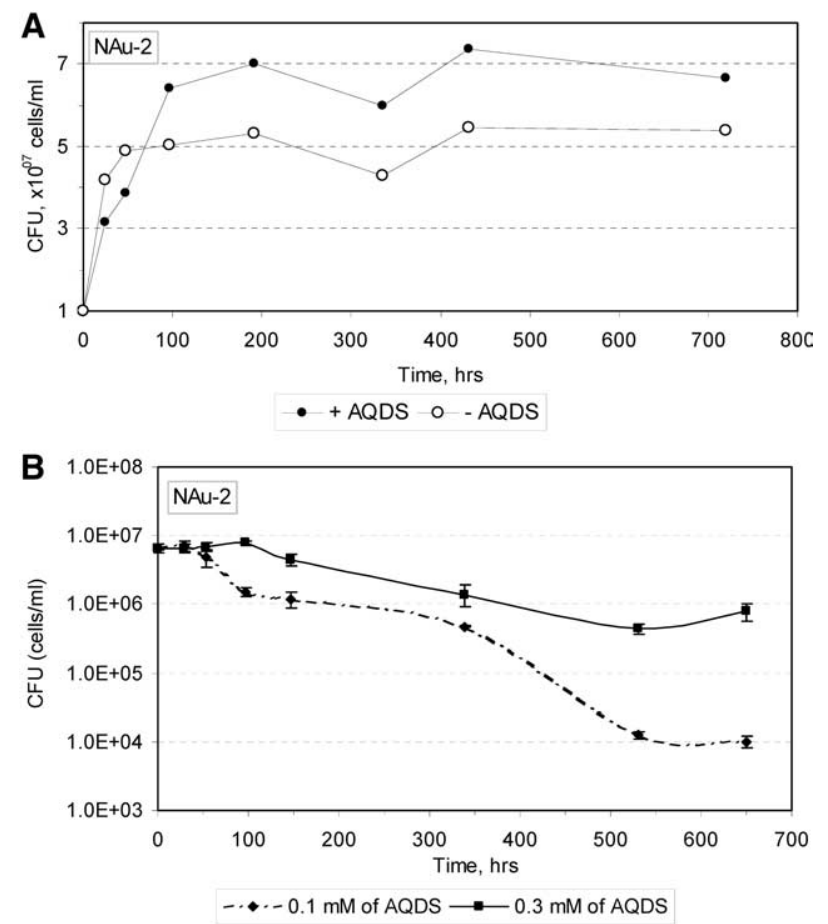

Fig. 7. A) Cell growth in a separate reduction experiment. The growth is higher in early days with different rate in the treatment with and without AQDS. Initial cell concentration was $1.17 \times 10^{7}$ cells $/ \mathrm{mL}$. B) Cell growth in the experiment where AQDS was used as the sole electron acceptor. 


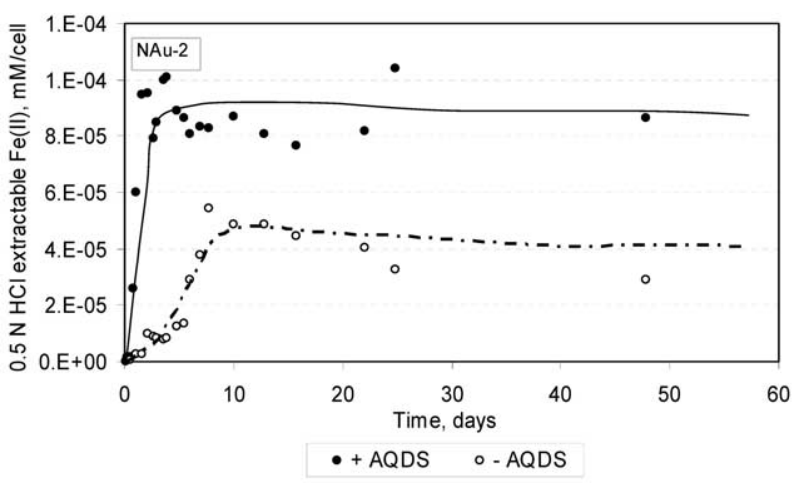

Fig. 8. Reduction of Fe(III) per cell with time in a separate experiment treated with and without AQDS. The control experiments did not show any reduction (data not shown).

To understand why nontronite clays were capable of supporting cell growth without externally supplied growth supporting nutrients such as trace metals and vitamins, trace metal and other nutrient concentrations in the NAu-1 and NAu-2 separates used for the bioreduction experiments were analyzed (Table 1A and 1B). The result showed the existence of $\mathrm{C}, \mathrm{N}$, and $\mathrm{P}$ sources as well as trace metals in the nontronite materials to support growth of CN32 cells.

\subsubsection{X-Ray diffraction}

XRD results of the bioreduced NAu- 1 and NAu-2 did not show any presence of biogenic solids such as siderite. Nontronite was the only solid remaining at the end of the bioreduction experiments, besides any other coexisting minerals that were native with NAu-1. The crystallite thickness remained nearly the same after the bioreduction in NAu-1 (Table 2) without change in crystal size distribution (CSD). In contrast, microbial reduction decreased nontronite crystallite thickness from $6 \mathrm{~nm}$ to $3.5 \mathrm{~nm}$ in NAu-2. The reduction process also changed crystal size distribution from lognormal to asymptotic shape. The experiments performed with higher $\mathrm{K}$ concentration $(54 \mathrm{mM})$ of NAu-2 showed an increase in layer charge (from 0.47 to $0.61)$.

\subsubsection{Transmission electron microscopy}

Similar to XRD, TEM observations revealed no biogenic solids other than residual nontronite. However, TEM data of

Table 1A. Trace metal concentration in NAu-1 and NAu-2.

\begin{tabular}{lcc}
\hline \multicolumn{1}{c}{ Trace metal } & $\begin{array}{c}\text { Concentration }(\mu \mathrm{M} / \mathrm{g}) \\
\text { in NAu-1 }\end{array}$ & $\begin{array}{c}\text { Concentration } \\
(\mu \mathrm{M} / \mathrm{g}) \\
\text { in NAu-2 }\end{array}$ \\
\hline Cobalt (Co) & 0.0 & 0.1 \\
Molybdenum (Mo) & 0.1 & 0.1 \\
Nickel (Ni) & 0.9 & 1.2 \\
Zinc (Zn) & 0.7 & 1.8 \\
Manganese (Mn) & 0.5 & 0.3 \\
Cupper $(\mathrm{Cu})$ & 0.7 & 0.4 \\
Boron $(\mathrm{B})$ & 7.0 & 19.5 \\
\hline
\end{tabular}

Concentrations are expressed as $\mu$ mol per gram of clay. the bioreduced, AQDS-treated NAu-2 revealed that the clay particles showed more flocculated morphology than the unreduced NAu-2 (Figs. 9A and 9B). The flocs were non homogeneous and distributed unevenly in the sample. The close association of nontronite and bacterial cells was common (Fig. 9B). Many cells showed accumulation of electron dense material that produced a halo-like feature around them. The halo, however, did not appear uniform around each cell. The cell surface bound materials were suggested as a result of the accumulation of smectite particles (Dong et al., 2003a), cell metabolic products (Li et al., 2004) and/or Fe(II) ions (Rancourt et al., 2005). From the results of adsorption experiment (not included here), we suggest that the accumulation of biogenic Fe(II) onto cell surfaces might have contributed to the formation of the halolike features. There was no independent evidence, however, that these features were the results of accumulation of biogenic solids, metabolic products, or Fe(II) ions. The internal structure of the cell was not clear and appeared different among one another, which was probably due to poor staining through the thick halo-like layer.

\subsubsection{Mössbauer spectroscopy}

The $12 \mathrm{~K}$ Mössbauer spectra of the bioreduced materials were quite different between NAu-1 and NAu-2 (Figs. 10 and 11) and from those of their respective starting materials (Figs. 1 and 2). In NAu-1, the sextet that consisted of $12 \%$ of $\mathrm{Fe}(\mathrm{III})$ was completely removed after bioreduction (Fig. 10), suggesting that $\mathrm{Fe}$ (III) in goethite was completely reduced. There was an emergence of a side doublet with Mössbauer parameters characteristic of $\mathrm{Fe}(\mathrm{II})$. The central doublet [cis-octahedral $\mathrm{Fe}(\mathrm{III})]$ remained in the same peak position but the peak area slightly decreased, suggesting that the octahedral Fe(III) was only slightly bioreduced. The increase in the amount of Fe(II) approximately corresponded to the sum of the amount of $\mathrm{Fe}(\mathrm{III})$ in goethite and a small amount of decrease of $\mathrm{Fe}(\mathrm{III})$ in nontronite.

A fit of the room temperature spectrum of the bioreduced NAu-2 indicated that the $\mathrm{Fe}$ (II) contribution to the spectrum was $\sim 25 \%$ (Fig. 11A). The amount of Fe(II) as determined from this spectrum was probably not due to weak adsorption onto cell or in the interlayer sites of the nontronite structure because adsorbed Fe(II) onto cell walls (Rancourt et al., 2005) or in the interlayer (Diamant et al., 1982) would display weak or zero Mössbauer signal at room temperature. Furthermore, the Fe(II) Mössbauer parameters at $77 \mathrm{~K}$ (data not shown) were different from those $\mathrm{Fe}(\mathrm{II})$ adsorbed onto bacterial cell surfaces ( $\delta=1.3$ to $1.4 \mathrm{~mm} / \mathrm{s}$, and $\Delta=3.3$ to $3.4 \mathrm{~mm} / \mathrm{s}$ ). The difference in the amount of $\mathrm{Fe}$ (II) between RT and $12 \mathrm{~K}(\sim 14 \%)$ was due to the presence of surface adsorbed $\mathrm{Fe}(\mathrm{II})$, since surface adsorbed $\mathrm{Fe}$ (II) becomes visible at low temperature because of increase in the recoil-free fraction. Thus, we concluded that the biogenic $\mathrm{Fe}(\mathrm{II})$ was partitioned between surface adsorption and structural association with nontronite.

The $12 \mathrm{~K}$ spectrum of the bioreduced NAu-2 showed that the increase in the $\mathrm{Fe}$ (II) doublet content appeared predominantly at the expense of the disappearance of the trans-octahedral $\mathrm{Fe}$ (III). The modeling for the Fe(II) doublet with isomer shift of $+1.2 \mathrm{~mm} / \mathrm{s}$ and quadrupole splitting of $2.8 \mathrm{~mm} / \mathrm{s}$ showed the total $\mathrm{Fe}(\mathrm{II})$ of $37 \%$ in the bioreduced solids. The absence of magnetic order at $12 \mathrm{~K}$ indicated the absence of siderite (Wade 
Table 1B. Major nutrients available for cell growth in NAu-1 and NAu-2

\begin{tabular}{lccccc}
\hline Nontronite & Total Nitrogen, \% & Total Carbon, \% & $\begin{array}{c}\text { Available } \\
\text { Phosphorous, mg/g }\end{array}$ & $\begin{array}{c}\text { Inorganic } \\
\text { Carbon, \% }\end{array}$ & $\begin{array}{c}\text { Organic } \\
\text { Carbon, \% }\end{array}$ \\
\hline NAu-1 & 0.021 & 0.03 & 0.003 & 0.002 & 0.032 \\
NAu-2 & 0.012 & 0.019 & 0.001 & 0.004 & 0.015 \\
\hline
\end{tabular}

et al., 1999) and green rust (Ona-Nguema et al., 2002), commonly observed biogenic minerals in bicarbonate buffer (Fredrickson et al., 1998; Dong et al., 2003b).

The inner doublet feature, which was a mix of the tetrahedral and the cis-octahedral $\mathrm{Fe}(\mathrm{III})$, decreased to a smaller extent (Fig. 11B). This extent of bioreduction was comparable to the total $\mathrm{Fe}$ (II) measured by the titration method which extracts both of the loosely adsorbed and $\mathrm{Fe}$ (II) in the nontronite, but slightly higher than the $0.5 \mathrm{~N} \mathrm{HCl}$ extractable $\mathrm{Fe}(\mathrm{II})(28 \%-$ $32 \%)$. The Mössbauer parameters for the central Fe(III) doublet ( $\delta=0.48 \mathrm{~mm} / \mathrm{s}$ and $\Delta=0.41 \mathrm{~mm} / \mathrm{s}$ ) were characteristic of the octahedral $\mathrm{Fe}(\mathrm{III})$, not tetrahedral $\mathrm{Fe}$ (III). Tetrahedral Fe(III) display $\delta$ and $\Delta$ values lower than octahedral Fe(III) (Goodman, 1978). A comparison between the unreduced and bioreduced NAu-2 spectra clearly showed absence of a feature in the bioreduced sample that could be assigned to the tetrahedral $\mathrm{Fe}(\mathrm{III})$. This evidence suggests the tetrahedral Fe(III), in addition to the trans-octahedral Fe(III), was also removed after the bioreduction, but the cis-octahedral Fe(III) (the central doublet in Fig. 11B) remained.

\section{DISCUSSION}

\subsection{Control of Fe(III) Site Occupancy on the Rate and Extent of Fe(III) Reduction in Nontronites}

Our reduction experiments performed with the same experimental parameters (same initial cell concentration, electron donor, electron acceptor) showed the different rate and extent of bioreduction in NAu-1 and NAu-2. In NAu-1, the measured amount of bioreduction occurred primarily from reduction of goethite, and the cis-octahedral Fe(III) was only reduced to a small extent. In NAu-2, the measured amount of bioreduction came from a combination of the tetrahedral $\mathrm{Fe}$ (III) and the trans-octahedral $\mathrm{Fe}(\mathrm{III})$, again the cis-octahedral $\mathrm{Fe}(\mathrm{III})$ was only slightly reduced.

Our data alone could not be used to determine the relative reducibility of $\mathrm{Fe}(\mathrm{III})$ in the tetrahedral and trans-octahedral sites. However, some inferences may be made by comparisons of our results with published data. Li et al. (2004) reported that when $\mathrm{Fe}(\mathrm{III})$ in NAu-2 was used as the sole electron acceptor, the extent of reduction was $10 \%$. This extent of reduction was similar to the fraction of total Fe(III) in the tetrahedral site (9\%) as determined by Gates et al. (2002) using X-ray absorption fine-structure spectroscopy methods. This extent was also similar to our measured extent for NAu-2 in the absence of AQDS (11\% at 15 days). When AQDS (in our study) or sulfate (in the $\mathrm{Li}$ et al. study) was present, the extent of reduction increased to 28 and 29\%, respectively. These data appear to imply that the tetrahedral $\mathrm{Fe}$ (III) was the only $\mathrm{Fe}$ (III) that was reduced in the absence of an electron transfer facilitator. When electron shuttle (AQDS) or alternative electron acceptor (sulfate) was present to either facilitate electron transfer or to promote metabolic activity of bacteria, the $\mathrm{Fe}$ (III) in the octahedral site became bioreducible. All these observations were consistent with an early study on reduction of nontronite by chemical reductants such as dithionite and hydrazine (Russell et al., 1979). The authors of that study reported that the nontronites that contained tetrahedral iron were much more extensively reduced by dithionite than were those that did not contain tetrahedral iron, and that this iron was preferentially dissolved after reduction.

The preferential reduction and dissolution of $\mathrm{Fe}(\mathrm{III})$ in the tetrahedral site may be accounted for based on the crystal chemical viewpoints. Since the ionic radius of $\mathrm{Fe}(\mathrm{II})$ is too large to fit into the tetrahedral site, the reduction of $\mathrm{Fe}$ (III) to $\mathrm{Fe}$ (II) would result in instability of the tetrahedral site and possible structural breakdown. The bioreduction of the transoctahedral $\mathrm{Fe}$ (III) would further induce structural instability. Indeed, the microbial reduction of $\mathrm{Fe}(\mathrm{III})$ in the NAu-2 caused decrease in crystallite size of nontronite, change in crystal size distribution, and release of $\mathrm{Si}$ into aqueous solution. These data were all consistent with a reductive dissolution mechanism for NAu-2 by bacteria. In contrast, the bioreduction of Fe(III) in NAu-1 did not significantly change the crystal thickness or crystal size distribution, suggesting that the nontronite structure remained intact after the bioreduction. Indeed, goethite in $\mathrm{NAu}-1$ was the predominant phase that was bioreduced.

Additional factors responsible for the observed difference in

Table 2. Crystal size and distribution before and after bioreduction in NAu-1 and NAu-2.

\begin{tabular}{llccl} 
& & \multicolumn{2}{c}{ Nontronite Crystallite } & \\
\cline { 3 - 4 } Sample & Treatment & Thickness, nm & Shape distribution & \\
\hline \multirow{2}{*}{ NAu-1 } & Control & 2.1 & Mineralogy \\
& w/o AQDS & 2.4 & Asymptotic & Smectite, kaoline, traces of illite, quartz, calcite \\
& AQDS & 2.4 to 2.5 & Asymptotic & Smectite, kaoline, traces of illite, quartz \\
NAu-2 & Control & 6.0 & Asymptotic & Smectite, kaoline, traces of illite, quartz \\
& AQDS & 3.5 & Lognormal & Smectite \\
& & & Asymptotic & Smectite \\
\hline
\end{tabular}

$\mathrm{NA}=$ not analyzed 

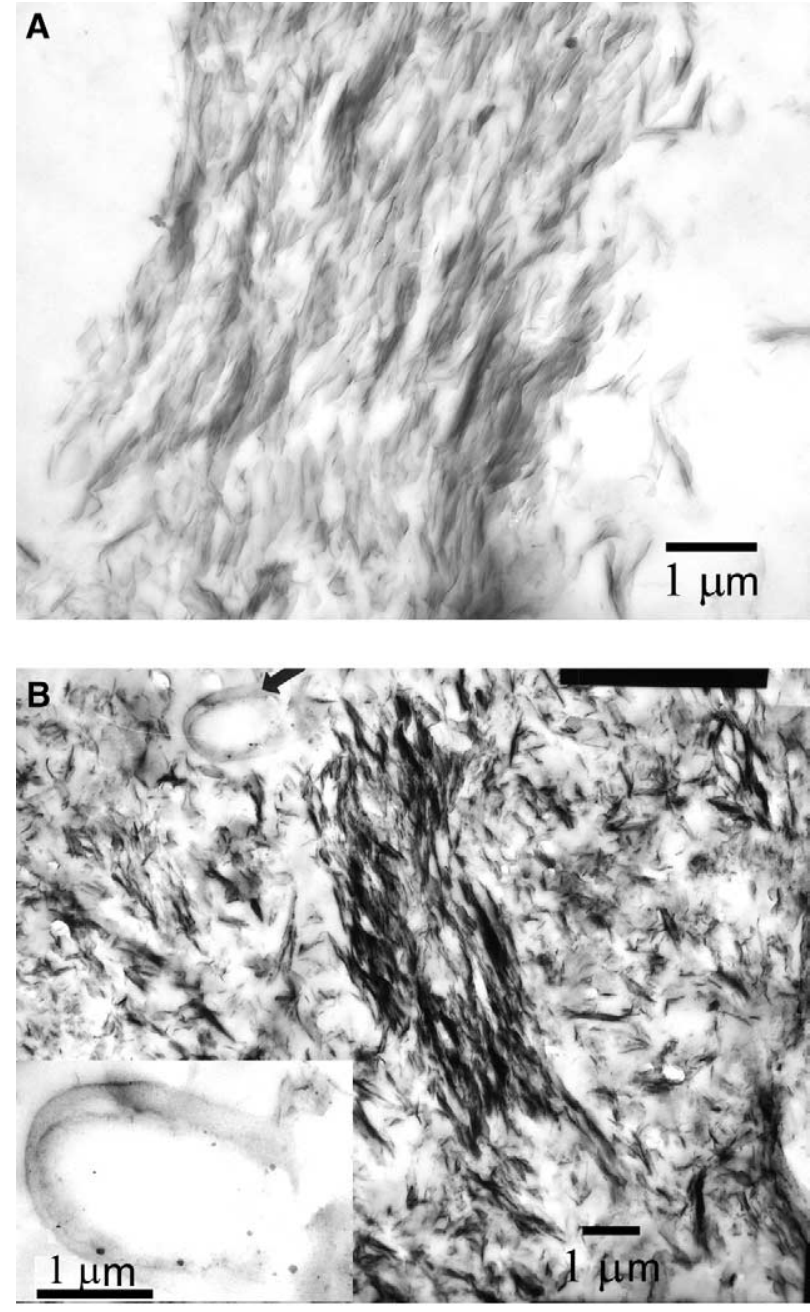

Fig. 9. A) Bright field TEM image of the unreduced NAu-2 in the control experiment. B) The NAu-2 particles in the bioreduced sample showing flocculated morphology. The cell in inset shows the accumulation of electron dense materials around cell surface.

the bioreduction behaviors between NAu-1 and NAu-2 may have come from layer charge. The layer charge of NAu-1 (1.05) was higher than that of NAu-2 (0.72) (Gates et al., 2002). The higher charge of NAu-1 would suggest less bioreduction. In the extreme case when the layer charge is close to 2 per 22 oxygens (i.e., illite), the extent of bioreduction was small and the rate was low (Dong et al., 2003a).

The results of this study also point out the importance of growth medium in affecting the extent and rate of bioreduction. Kim et al. (2004) conducted bioreduction experiment of NAu-1 and the extent of reduction was higher than that of this study. The important differences are probably the medium composition and cell type. In the Kim et al. (2004) study, a growth medium was used, including basal salts, trace elements, vitamins, amino acids, phosphates, and carbon sources. However, pure bicarbonate buffer was used in our experiments with no nutrients other than carbon source lactate. Indeed, more than one order of magnitude increase in cell number was observed over 3 days of experimental period using the M1 medium with $\mathrm{Fe}(\mathrm{III})$ in smectite as the
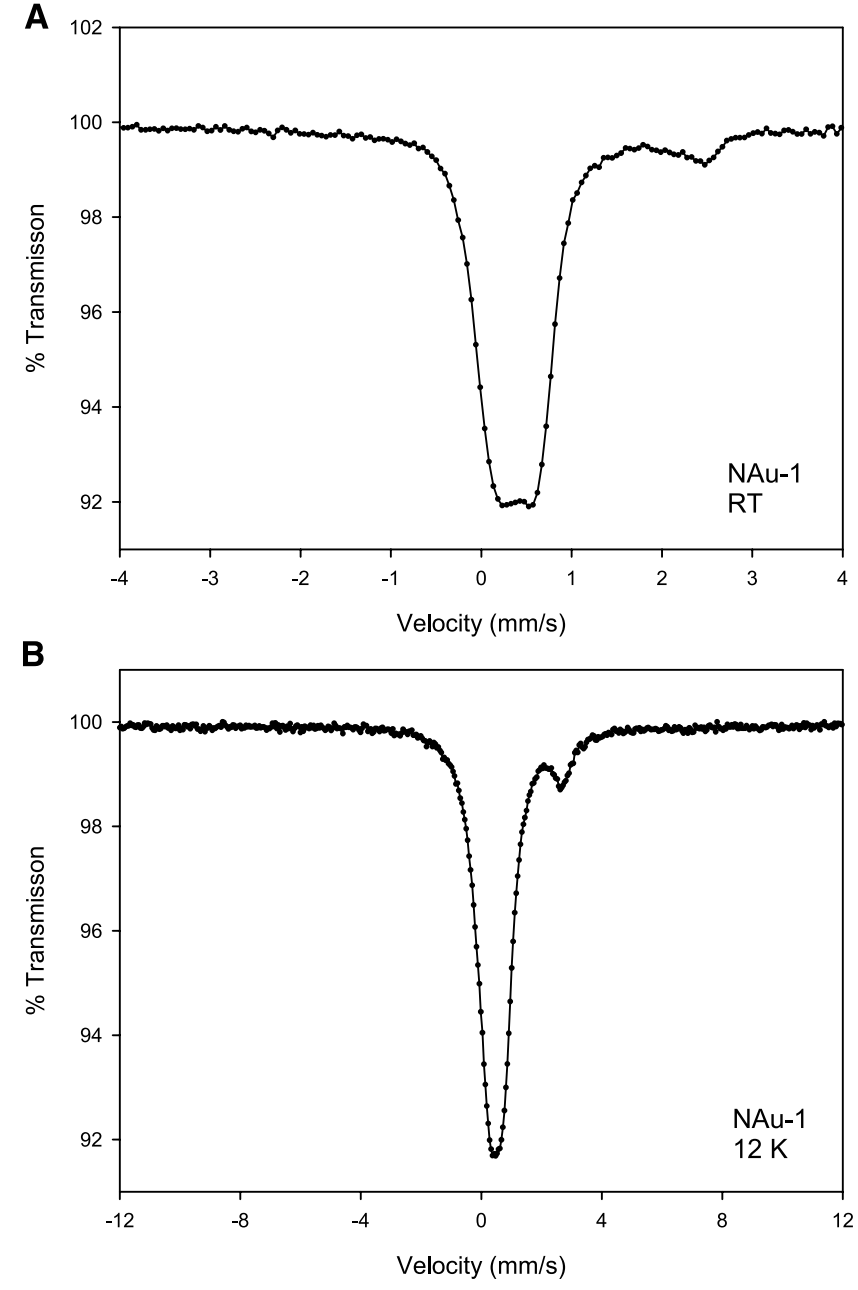

Fig. 10. Mössbauer spectra of the bioreduced material of NAu-1 at RT (A) and $12 \mathrm{~K}$ (B). The spectra show the development of a prominent $\mathrm{Fe}$ (II) doublet as a result of bioreduction, and removal of sextet ascribed to goethite.

sole electron acceptor (Kim et al., 2004) and the cell growth would be expected to continue if the experiments were run longer (Kostka et al., 2002). Although relatively slow cell growth was observed in our medium without added nutrients, it was limited within an order. Different bacteria used in the studies may have been partially responsible for the observed differences: Shewanella putrefaciens strain CN32 was used in our study, $S$. oneidensis strain MR1 was used in the Kim et al. study. Different bacteria may have different abilities to reduce $\mathrm{Fe}(\mathrm{III})$ to support their growth. Other variables affecting bioreduction include bacteria/clay concentration ratio, presence or absence of electron shuttle, surface area, etc.

\subsection{Cell Growth in the Medium without Added Nutrients}

The sterility in the controls (without initial addition of CN32 cells at the beginning of the experiments) and single morphology type characteristic of $\mathrm{CN} 32$ strongly indicated that cell growth observed in our study was not due to contamination. 

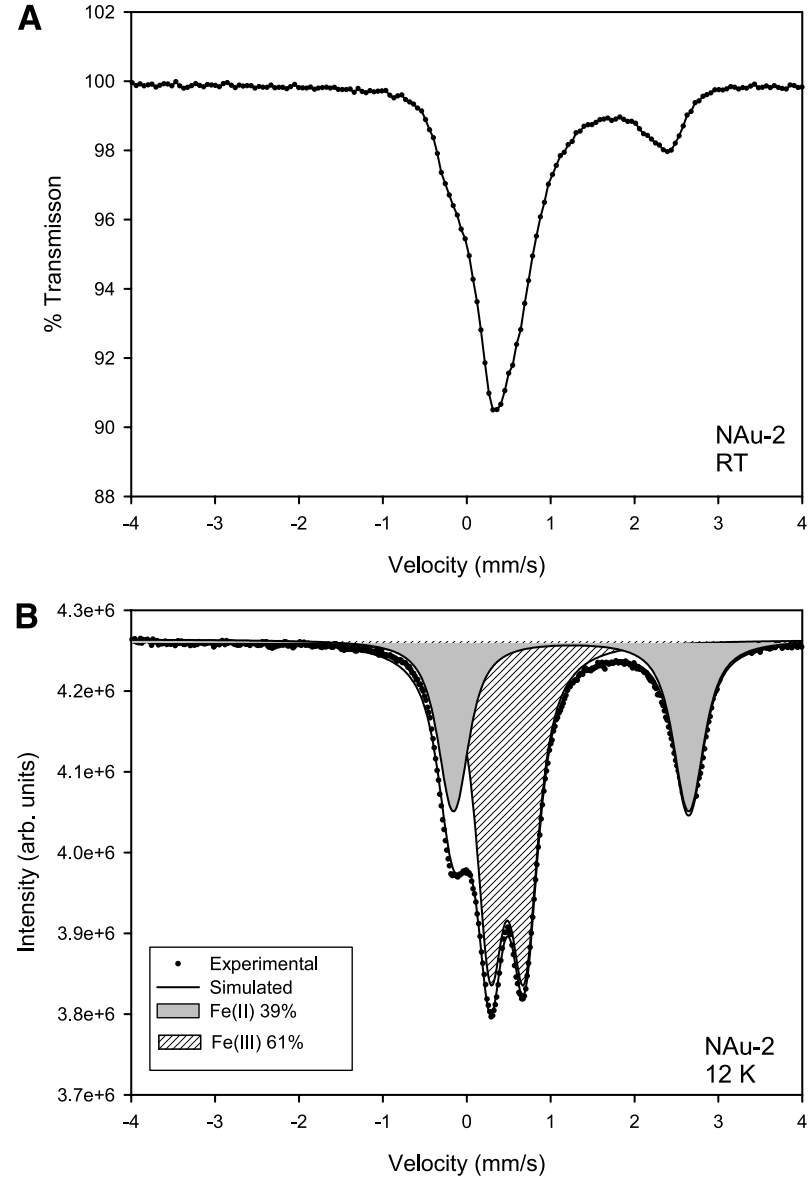

Fig. 11. Mössbauer spectra of the bioreduced NAu-2 nontronite at RT (A) and $12 \mathrm{~K}$ (B) with a modeled curve superimposed. Relative to the unreduced NAu-2, the spectra show emergence of $\mathrm{Fe}(\mathrm{II})$ doublet, removal of trans-octahedral and tetrahedral $\mathrm{Fe}(\mathrm{III})$ after bioreduction. The cis-octahedral $\mathrm{Fe}(\mathrm{III})$ is not reduced.

The increase in the cell number by a factor of $\sim 5$ and 7 in the treatment without and with AQDS, respectively, suggests that a minimal medium with sufficient electron donor (lactate) and electron acceptor [Fe(III) in nontronite] may be able to support cell growth in the presence of nontronite. The cell growth was not observed when AQDS was used the sole electron acceptor. Since we used only 0.1 and $0.3 \mathrm{mM}$ of AQDS, it should be quickly consumed thereby resulting in loss of viable cells. When AQDS was used in conjunction with clay, it should constantly be regenerated from its reduced form (AHDS), thus facilitating electron transfer.

The nontronite samples contained abundant elements such as $\mathrm{Na}, \mathrm{K}, \mathrm{Mg}, \mathrm{Ca}, \mathrm{P}, \mathrm{Zn}$ (Table 3, Keeling et al., 2000; Table 1 Gates et al., 2002), which are major and minor nutrient for cells. Measurement of trace metals and nutrient elements required for cell growth (Table 1A and B) showed that both $\mathrm{NAu}-1$ and NAu-2 contained organic nutrients such as $\mathrm{C}, \mathrm{N}$ and $\mathrm{P}$, and trace metals to support cell growth. Li et al. (2004) observed that native NAu-2 was able to support growth of Desulfovibrio spp. strain G-11. When trace elements and vitamins were removed by $\mathrm{NaCl} / \mathrm{HCl}$ treatment, bacterial growth was significantly slowed. These data were consistent with the findings by Krumholz and his colleagues in that clay-rich shales are able to provide nutrients to adjacent sandstones to support microbial growth (Krumholz, 1997; Krumholz, 2000).

\subsection{Microbial Reduction of Nontronite and Formation of Illite}

The extended reduction experiment for three and six months suggests that AQDS only enhanced the rate of bioreduction of $\mathrm{Fe}(\mathrm{III})$ in nontronites. The continued reduction over an extended time period in the absence of AQDS suggests that the extent of bioreduction may reach that in the AQDS system within a few more months of bioreduction. This suggests that microbial reduction of $\mathrm{Fe}(\mathrm{III})$ in nontronite is a favorable reaction, and AQDS only catalyzes the reaction.

Several experiments performed with a minimum amount of potassium content $(1.3 \mathrm{mM})$ did not produce any illite during bioreduction of NAu-2. Using a chemically defined growth medium (M1) and K concentration of 10 mM, Kim et al. (2004) observed formation of illite when nontronite was microbially reduced. The M1 medium contained amino acids, trace metals, vitamins, basal salts, phosphates, and various carbon sources. In contrast, the medium used in the present study was closer to natural conditions and only contained lactate, nontronite, bicarbonate buffer, and AQDS (in selected experiments). When the concentration of potassium, often a limiting factor in the smectite to illite reaction, was increased to $54 \mathrm{mM}$, an increase in layer charge from 0.47 to 0.61 was observed by XRD. Increase in the total layer charge has been observed in reduced smectite (Stucki et al., 1984c). Although such a layer charge was not high enough to form illite, it could be considered as an intermediate step toward illite formation. However, formation of illite requires carefully controlled solution chemistry, such as external supply of $\mathrm{Al}$ and K. Further experiments are currently underway to specifically address these questions.

\section{CONCLUSIONS}

The extent and rate of microbial reduction of $\mathrm{Fe}$ (III) in NAu-1 and NAu-2 was controlled by distribution of $\mathrm{Fe}(\mathrm{III})$ in different structural sites and layer charge. Mössbauer data indicated that in NAu-1, Fe(III) was present in the cis-octahedral site (M2) only, whereas in NAu-2, Fe(III) was distributed in the tetrahedral, the cis-octahedral and the trans-octahedral sites. As a result of bioreduction, the Fe(III) in the tetrahedral and the trans-octahedral sites was bioreduced, but the cisoctahedral $\mathrm{Fe}(\mathrm{III})$ remained relatively unchanged. This differential bioreduction of $\mathrm{Fe}(\mathrm{III})$ in different structural sites was magnified by addition of an electron shuttle, AQDS. In the absence of AQDS, the extent of bioreduction for NAu-1 and NAu-2 was 5\%-7 and 14\%-18\%, respectively. In the presence of AQDS, the resulting extent of bioreduction for NAu-1 was $11 \%-16 \%$, whereas that for NAu-2 was $28 \%-32 \%$. No biogenic solids were observed. Shewanella putrefaceins CN32 was able to reduce $\mathrm{Fe}$ (III) in clay structure without direct contact. Cell growth was observed in the medium without added nutrients that contained nontronite, bicarbonate buffer and lactate only. The nontronites contained carbon and trace elements that would be released as a result of reductive dissolution and would support bacterial cell growth. 
Acknowledgments-Acknowledgment is made to the donors of The Petroleum Research Fund, administered by the ACS, for partial support of this research. This research was also supported by a grant from National Science Foundation (EAR-0345307) to HD. Mössbauer measurements were performed within the DOE/OBER Environmental Molecular Sciences Laboratory user facility. Pacific Northwest National Laboratory (PNNL) is operated for the U.S. Department of Energy by Battelle Memorial Institute under Contract DE-AC06-76RLO 1830. Some part of this research was supported by student grants from the Clay Mineral Society (Student Research Grant, 2004) and AAPG (John Teagle Memorial Grant, 2004) to DPJ. We are grateful to John Morton for his help in the DCP analyses. DPJ is grateful to J. Seabaugh for her initial training in the microbial work. We thank Jeremy Fein, Johnson Haas, and two anonymous reviewers for improving the quality of the manuscript.

Associate editor: J. B. Fein

\section{REFERENCES}

Achtnich C., Schuhmann A., Wind T. and Conrad R. (1995) Role of interspecies $\mathrm{H}_{2}$ transfer to sulfate and ferric iron-reducing bacteria in acetate consumption in anoxic paddy soil. FEMS Microbiol. Ecol. 16, 61-70.

Andradae S., Hypolito R., Ulbrich H. H. and Silva M. L. (2002) Technical note iron (II) oxide determination in rocks and minerals. Chem. Geol. 182, 85-89.

Bailey S. W. (1984) Classification and structures of the micas. Rev. Mineral. 13, 1-12.

Boone D. R., Liu Y., Zhao Z., Balkwill D. L., Drake G. R., Stevens T. O. and Aldrich H. C. (1995) Bacillus infernus Sp. Nov., an $\mathrm{Fe}(\mathrm{III})$ - and $\mathrm{Mn}(\mathrm{IV})$-reducing anaerobe from the deep terrestrial subsurface Int. J. Sys. Bacteriol. 45, 441-448.

Boslough M. B., Venturini B. M. and Graham R. A. (1986) Physical properties of shocked and thermally altered nontronite: Implications for Martial surface. Proc. Seventeenth Lunar and Planetary Sci. Conf., Part 1. J. Geophys. Res. 91, E207-E214.

Cardille C. M., Johnston J. H. and Dickson D. P. E. (1986) Magnetic ordering at 4.2 and $0.3 \mathrm{~K}$ in nontronites of different iron contents: a ${ }^{57} \mathrm{Fe}$ Mössbauer spectroscopic study. Clays Clay Mineral. 34, 233-238.

Christidis G. E. and Eberl D. D. (2003) Determination of layer-charge characteristics of smectites. Clays Clay Mineral. 51, 644-655.

Daynyak L. G. and Drits V. A. (1987) Interpretation of Mössbaouer spectra of nontronite, celadonite and glauconite. Clays Clay Mineral. 35, 363-372.

Dong H., Kukkadapu R. K., Fredrickson J. K., Zachara J. M., Kennedy D. W. and Kostandarithes H. M. (2003a) Microbial reduction of structural $\mathrm{Fe}(\mathrm{III})$ in illite and goethite. Environ. Sci. Technol. 37, $1268-1276$

Dong H., Kostka J. E. and Kim J. (2003b) Microscopic evidences for microbial dissolution of smectite. Clays Clay Mineral. 51, 502512.

Drits V. A., Eberl D. D. and Írodoñ J. (1998) XRD measurements of mean thickness, thickness distribution and strain for illite and illite-smectite crystallites by the Bertaut-Warren-Averbach technique. Clays Clay Mineral. 46, 38-50.

Eberl D. D., Drits V. A and Irodoñ J. (2000) User's guide to GALOPER - a program for simulating the shapes of crystal size distributions-and associated programs. U.S. Geol. Surv. Open File Rep. (OF 00-505), $44 \mathrm{pp}$.

Fredrickson J. K., Zachara J. M., Kennedy D. W., Dong H., Onstott T. C., Hinman N. W. and Shu-mei L (1998) Biogenic iron mineralization accompanying the dissimilatory reduction of hydrous ferric oxide by a groundwater bacterium. Geochim. Cosmochim. Acta 62, 3239-3257.

Gates W. P., Slade P. G., Manceau A. and Lanson B. (2002) Site occupancies by iron in nontronites. Clays Clay Mineral. 50, 223 239.

Goodman B. A. (1978) An investigation by Mössbauer and EPR spectroscopy of the possible presence of iron-rich impurity phases in some montmorillonites. Clay Minerals 13, 351-356.
Goodman B. A., Russell J. D. and Fraser A. R. (1976) A Mössbauer and I. R. spectroscopic study of the structure of nontronite. Clays Clay Mineral. 24, 53-59.

Janot C., Chabanel H. and Herzog E. (1973) E'tude d'une limonite par effect Mössbauer. Bull. Soc. Fran. Miner. Cristl. 91, 166-176.

Katoh S., Danhara T., Hart W. K. and Wolde-Gabriel G. (1999) Use of sodium polytungstate solution in the purification of volcanic glass shards for bulk chemical analysis. Nat. Human Act. 4, 45-54.

Keeling J. L., Raven M. D. and Gates W. P. (2000) Geology and characterization of two hydrothermal nontronites from weathered metamorphic rocks at the Uley graphite mine, South Australia. Clays Clay Mineral. 48, 537-548.

Kim J., Dong H., Seabaugh J., Newell S. and Eberl D. (2004) Role of microbes in the smectite-illite reaction. Science 303, 830-832.

Komadel P. (1999) Structure and chemical characteristics of modified clays. In Natural Microporous Materials in Environmental Technology (eds. P. Misaelides, F. Macasek, T. J. Pinnavaia and C. Colella), pp. 3-18. Kluwer Academic Publishers, Dordrecht.

Komadel P., Lear P. R. and Stucki J. W (1990) Reduction and reoxidation of nontronite: Extent of reduction and reaction rates. Clays Clay Mineral. 38, 203-208.

Komadel P., Grygar T. and Mehner H. (1998) Reductive dissolution and Mössbauer spectroscopic study of Fe forms in the fine fractions of Slovak Fe-rich bentonites. Clay Minerals 33, 593-599.

Kostka J. E., Dalton D., Skelton H., Dollhopf S. and Stucki J. W (2002) Growth of iron(III)-reducing bacteria on clay minerals as the sole electron acceptor and a growth yield comparison on a variety of oxidized iron forms. Appl. Environ. Microbiol. 68, 6256-6262.

Kostka J. E., Haefele E., Viehweger R. and Stucki J. W. (1999a) Respiration and dissolution of Fe(III)-containing clay minerals by bacteria. Environ. Sci. Technol. 33, 3127-3133.

Kostka J. E., Wu J., Nealson K. H. and Stucki J. W. (1999b) The impact of structural $\mathrm{Fe}$ (III) reduction by bacteria on the surface chemistry of clay minerals. Geochim. Cosmochim. Acta 63, 3705-3713.

Krumholz L. R., McKinley J. P. and Ulrich F. A. (1997) Confined subsurface microbial communities in Cretaceous rock. Nature 386, $64-66$.

Krumholz L. R. (2000) Microbial communities in the deep subsurface. Hydrogeol. J. 8, 4-10.

Kukkadapu R. K., Zachara J. M., Fredrickson J. K., Kennedy D. W. (2004) Biotransformation of two-line silica-ferrihydrite by a dissimilatory $\mathrm{Fe}(\mathrm{III})$-reducing bacterium: formation of carbonate green rust in the presence of phosphate. Geochim. Cosmochim. Acta 68, 2799-2814.

Li Y. L., Vali H., Sears S. K., Yang J., Deng B. and Zhang C. (2004) Iron reduction and alteration of nontronite NAu-2 by a sulfate reducing bacterium. Geochim. Cosmochim. Acta 68, 3251-3260.

Lovley D. (1995) Bioremediation of organic and metal contaminants with dissimilatory metal reduction. Environ. Sci. Technol. 14, 85-93.

Lovley D. R., Baedecker M. J., Lonergan D. J., Cozzarelli I. M., Phillips E. J. P. and Siegal D. I. (1989b) Oxidation of aromatic contaminants coupled to microbial iron reduction. Nature 339, 297-299.

Lovley D. R. and Lloyd J. R. (2000) Microbes with a mettle for bioremediation. Nat. Biotech. 18, 600-601.

Lovley D. R., Kashefi K., Vargas M., Tor J. M. and Blunt-Harris E. L (2000) Reduction of humic substances and Fe(III) by hyperthermophilic microorganisms. Chem. Geol. 169, 289-98.

Lovley D. R., Holmes D. E., Nevin K. P. (2004) Dissimilatory Fe(III) and Mn(IV) reduction. Adv. Microbial Physiol. 49, 219-286.

Luca V. (1991a) Detection of tetrahedral $\mathrm{Fe}^{3+}$ sites in nontronite and vermiculite by Mössbauer-spectroscopy. Clays Clay Miner. 39, 467-477.

Luca V. (1991b) ${ }^{57} \mathrm{Fe}$ Mössbauer spectroscopic study of structural changes during dehydration of nontronite: effects of different exchangeable cations. Clays Clay Mineral. 39, 478-489.

Luca V. and Cardille C. M. (1989) Improved detection of tetrahedral $\mathrm{Fe}^{+3}$ in nontronite SWa-1 through Mössbauer spectroscopy. Clay Minerals 24, 115-119.

Luca V. and Maclachlan D. J. (1992) Site occupancy in nontronite studied by acid dissolution and Mössbauer-spectroscopy. Clays Clay Miner. 40, 1-7.

Madejova J., Bujdak J., Janek M., Komadel P. (1998) Comparative FTIR study of structural modifications during acid treatment of 
dioctahedral smectites and hectorite. Spectrochim. Acta 54, 1397 1406.

Manceau A., Lanson B., Drits V. A., Chateigner D., Gates W. P., Wu J., Huo D., Stucki J. W. (2000a) Oxidation-reduction mechanism of iron in dioctahedral smectites. 1. Crystal chemistry of oxidized reference nontronites Am. Mineral. 85, 133-152.

Manceau A., Lanson B., Drits V. A., Chateigner D., Wu J., Huo D., Gates W. P. and Stucki. J. W (2000b) Oxidation-reduction mechanism of iron in dioctahedral smectites. 2. Crystal chemistry of reduced Garfield nontronite. Am. Mineral. 85, 153-172.

Murad E. and Cahsion J. (2004) Mössbauer spectroscopy of environmental materials and industrial utilization. Kluwer Academic Publisher.

Newman D. K. and Kolter R., (2000) A role for excreted quinones in extracellular electron transfer. Nature 405, 94-97.

Ona-Nguema G., Abdelmoula M., Jorand F., Benali O., Géhin A., Block J.-C. and Génin J-M. R (2002). Iron (II,III) hydroxycarbonate green rust formation and stabilization from lepidocrocite bioreduction. Geochim. Cosmochim. Acta 36, 16-20.

Osthaus B. B. (1956) Kinetic studies on montmorillonites and nontronites by the acid dissolution technique. Clays Clay Mineral. 4, 301-321.

Rancourt D. G. and Ping J. Y. (1991) Voigt-based methods for arbitrary-shape static hyperfine parameter distributions in Mössbauer spectroscopy. Nucl. Instr. Meth. Phys. Res. B. 58, 85-97.

Rancourt D. G., Lamarche G., Mavrocordato D., and Thibault P. J. (2005) Hydrous ferric oxide precipitation in the presence of nonmetabolizing bacteria: constraints on the mechanism of a biotic effect. Geochim. Cosmochim. Acta 69, 553-577.
Rosso K. M., Zachara J. M., Fredrickson J. K., Gorby Y. A. and Smith S. C. (2003) Nonlocal bacterial electron transfer to hematite surfaces. Geochim. Cosmochim. Acta 67, 1081-1087.

Russell J. D., Goodman B. A. and Fraser A. R. (1979) Infrared and Mössbauer studies of reduced nontronites. Clays Clay Mineral. 27, 63-71.

Stucki J. W. (1988) Structural iron in smectites. In Iron in Soils and Clay Minerals (eds. J. W. Stucki, B. A. Goodman and W. Schwertmann), pp. 625-675. D. Reidel, Dordrecht

Stucki J. W. (2005) Iron redox processes in smectites. In Handbook of Clay Science (eds. F. Bergaya, B. K. G. Theng and G. Lagaly). Elsevier, Amsterdam (Draft Version).

Stucki J. W., Golden D. C. and Roth C. B. (1984c) The effect of reduction and reoxidation on the surface charge and dissolution of dioctahedral smectites. Clays Clay Mineral. 32, 350-356.

Stookey L. L. (1970) Ferrozine- a new spectrophotometric reagent for iron. Anal. Chem. 42, 779-781.

Townsend M. G., Longworth G., Ross C. A. M. and Provencher R. (1987) Ferromagnetic or antiferromagnetic Fe(III) spin configurations in sheet silicates. Phys. Chem. Mineral. 15, 64-70.

Wade M. L., Agresti D. G., Wdowiak T. J. and Armendarez L. (1999) A Mössbauer investigation of iron-rich terrestrial hydrothermal vent systems: Lessons for Mars exploration. J. Geophy. Res. 104, 8489-8507.

Zachara J. M., Fredrickson J. K., Li S. W., Kennedy D. W., Smith S. C. and Gassman P. L. (1998) Bacterial reduction of crystalline Fe(III) oxides in single phase suspension and subsurface materials. Am. Mineral. 83, 1426-1443. 